\title{
E-mail 討論会
}

\section{ロボットエ学を考える}

参加者 白井 良明 大阪大学

前田 浩一 立命館大学

坪内 孝司 筑波大学

横井一仁 機械技術研究所
音田弘 電子技術総合研究所

尾形 哲也 早稲田大学大学院

奥山 健一 日本 IBM(株)

川内陽志生 東洋エンジニアリング(株)

司会：市川 誠 清水建設(株)

\section{1.「ロポットエ学」とは何か}

白井：ロボット学会を作った時の多くの人の動機の一つ は, 従来の学会では現象を解析しなければ研究とみなして くれず，論文にもなりにくかった，そ，そこでロボットを作 ったこと自体が評価されるような学会が欲しいということ でした，学会の対象は Roboticsです，当時，ロボット工 学とも訳されていましたが, 今ならロボット学でしょう か. 情報工学, 情報科学, 情報学というょうにいくつも可 能ですが，いずれにしても，単なる科学だけでなくSynthesis を行う工学も含めようということでしょう.

ところで, 大学で教えるロボット(工)学は，いろいろな 分野の知識を寄せ集めたような気がしますが，固有なもの は何でしょうか?

尾形：加藤一郎先生からどうして「ロボット工学会」では なく,「ロボット学会」なのかということで, 扔話しして頂 いた思い出があり，「工学」というと，どうしても産業に結 びついているイメージがあります. 大学に入るときにロボ ットをやりたいと思って何科に入ればいいんだろうと悩み ましたが, 結局, 加藤先生の名前で学科が決まりました. 大学に入ってからロボットについての講義というのは，ほ とんど無かったように思えましたが，その実はどの講義も ロボットの授業だったんじゃないかと, 研究室に入ってか ら思った訳です、ロボット学固有のものというと確かに良 くわからないですね。 ただ，「ロボコン」なんかをみてる と,「ロボット」という言葉には, やはり単なる機械とは違 う，なにか人を惹きつけるものがあるんだと思います．

奥山：私は，『ロボット』という時に必ず感じるのが、『解 放系』，『自律性』，『增殖性』の 3 つです.「生物」でも同 じことを感じるんで，固有のものではない気もします． 「ロボット学」は,「生物学」のアナロジーから見て次の 3 つ
が存在できると思います。で,「ロボット工学」というのは 特に今の状態では主に 1)を研究するのではなかろうかと 思います。

1）構造/機構に関する研究（どう作るか）

2) 生態関する研究(どう使うか/どう自己維持を果たす か)

3）進化/絶滅に関する研究(どう開発するか/どう壊すか) 音田：現在，ロボットについて何かを教えようとすると， それがいろいろな分野の知識を寄せ集めたようなものにな ってしまうというのは，私もわかるような気がします。そ れらの核となるべき固有の強力な原理は, まだ確立されて いないように思元ます。漠然と, 自律性, 適応性, 人間と の協調，意思疎通，汎用性，このようなことがその原理に 関わってくるだろうとは思っています。

川内：私は「ロボットの研究には八ードウェアがつきもの」 と考えて扔ります。極論すると「ハードウェアを対象とし ない研究は『ロボットの研究』では無い」と考元ます。勿 論, 制御理論やアルゴリズム (画像処理, NN, GA) の研 究を否定するものではありません。しかしこれら制御理 論, アルゴリズムの適用先がハードウェアでなければその 研究は「ロボットの研究ではない」と考元ます。この様な 考えを持っているものですから，以前「ロボット工学」/「口 ボット学」(Vol.10, No.1) の議論が有りましたが, 私に は「ロボット工学」と言った呼び方の方がしっくりします。 「ロボットの研究」はハードウェアに密接に関係した「工学」 であり、「理学」では無いと考えるからです。

白井：だいたい賛成です，ロボットの情報処理も大事です ので，このメールでは情報処理を取り上げます，情報処理 の中心的話題は人工知能 (AI) でしょう.おもしろいこと に, AI の分野では, roboticsがその一分野で, 実世界で 動くシステムの知能を対象としています。一方, robotics 
では，実世界と関係のない知能を AI に分類しています. だいたい賛成というのは，roboticsでは，実世界で動くシ ステムの知能を対象とすべきであるということです.

横井：「ロボット工学」はハードウェア（実世界）に密接し た研究であると思いますが，「ロボットの研究」は工学だけ に留まらないと思います。「ロボット社会学」，「ロボット 行動学」,「ロボット経済学」などの分野も出てくるのでは ないでしょうか.「造る立場」が「工学」なら，「使う立場」 がその他の学問領域になるのでしょうか.「自動車の研究」 が「自動車工学」のみで完結しないように

坪内：「ロボット社会学」や「ロボット行動学」とは,「人 間が，ロボットの集団の振舞いや行動をいかに規定し，役 立ち得る振舞いのために個々のロボットの行動をいかに設 計するかを考察する」学問，であり，これはロボットの側 ではなく，人間の側の問題意識であると考えています.

\section{2. ロボットに関する学科}

横井：Stanford大学, MIT, CMUの講義の内容を紹介 します。この調査には，MITに留学中の柴田氏（機械技 研), CMU に留学中の金子氏（機械技研）に協力していた だきました。

\section{[STANFORD UNIV.]}

Undergraduate or beginning graduate :

"Introduction to Robotics", "Introduction to Computer Vision", "Introduction to Mechatronics", "Introduction to Sensor”, "Dynamic Response”, "Feedback Control Design”, "State-Space Control Design”, "Robot Programming Laboratory", "Experimental Robotics"

Advanced graduate:

"Motion Planning”, “Advanced Robotic Manipulation", "Principles of Experimentation for Computer Vision", "Robotics and Vision Lab", "Mechatronic Systems Design and Methodology"

Experimental :

“Artificial Life", "Genetic Algorithms and Genetic Program”, "Experimental Robotics", "Robotics and Vision Lab", "Robot Programming Laboratory"

\section{[MIT]}

Undergraduate or beginning graduate :

"Dynamics", "Adaptive Control : Theory and Applications", "Machine Vision", "Robot Manipulation"

H-Level Grad Credit :

"Kinematics and Dynamics of Mechanisms and Manipulations", "Modeling and Simulation of Dynamic Systems", "Intelligent Control and Sensing”, "Robot Design and Control", "Human Supervisory Control of Telerobotics and Flight Vehicles", "Artificial Intelligence", "Concurrent Systems for Artificial Intelligence”, "The Society of Mind"

\section{[CMU]}

Undergraduate :

“AI : Computer vision”, "Robotic Manipulation”

Graduate :

"Fund. of AI in Robotics and Engineering", "Mech of Manipulation”, "Robot Control”, "Math Fundamentals for Robotics", "Mobile Robot Design”, "Seminar on Robotics”, "Special Topics in Robotics: Mechatronic", "Reading and Research"

白井：たくさんありますね. 1 学期間にとれる科目数は日 本より少ないと思います。ロボットの専門家養成という感 じです.かなり，自分で勉強をしないとついてゆけないで しょう。日本はこれまで会社へ入って役に立つように基礎 的なことをやっています。だから，機械，電気，制御とい うようになります。

前田：立命館大学では, 1996 年 4 月から理工学部にロボ ティクス学科が新設されます。そこでの講義科目について 紹介させていただきます。なお，ロボティクス学科の講義 科目は限られた時間と教員数の制約の中で立案したもの で，重要と思われるものでも割愛したり関連科目に小さく 押し込んだものが沢山あります。例えば，移動ロボット工 学, テレオペレーションなどです。立命館では大学院修士 課程まで含めた「ゆるやかな 6 年制教育なるものを推進し ておりまして，これらおよびさらに専門性が高い講義を大 学院で行うつもりで検討中です。一口にいうと「ヒューマ ンファクタに対する素養をもつメカトロ技術者」の養成を 目指しています。

\section{[立命館大学ロボティクス学科開講科目一覧 (基礎省略)] [学科共通専門科目]}

(1)講義科目群: ロボティクス概論, 力学, 計測工学, 生 体機能論, 電気電子回路, 知能科学, コンピュータ工学, 制御工学, ロボット機構学, 応用数学, ロボット設計論, 計算機制御，ロボット運動制御，オートメーション工学, 信号処理論, 福祉機械論

(2) 実験・実習・演習科目群：ロボティクス演習, ロボテ イクス実験, 力学演習, 科学技術英語, ロボティクス製作 実習, ロボット作業実習, マイクロマシニング実習, 卒業 研究

\section{[学科専門科目]}

( 3 )ロボットシステム関連科目群：ロボットアクチュエー 夕工学, ロボットセンサ工学, ロボット材料工学, マイク ロロボット工学, 応用ロボット工学

(4) ロボット知能関連科目群 : 接触力学, ロボット作業工 学, ロボットビジョン, 数理工学, 機械知能

( 5 ) ヒューマンマシン関連科目群: 運動・神経生理学, バ イオメカニクス, ヒューマンインターフェイス, 感性科 学, 仮想現実感工学 


\section{( 6 ) 特殊講義}

以上の中にロボティクス固有のもの，核となるものがあ ると思います。つぎに，これまでの皆様の議論に関しまし て, 私も「ロボティクス学科」新設の際に本校で議論いた しましたことをふまえてお話しさせていただきます。

\section{3.「ロボットエ学」「ロボット学」の考え方}

前田：まず，「ロボット工学」か「ロボット学」かの議論で すが，私もどちらでもよいと思います。とは言いながら語 感の問題があります．我々の間でも学科の名称をどうする かが大問題となりました，我々の議論は「ロボット工学」 (あるいはロボットという言葉自体)では現在の産業用ロボ ットのイメージが強すぎる, 現在の産業用ロボットを学ぶ だけでは 1 つの学科をつくるに值しないというものです．

これに対してロボットの概念はもっと広く，哚いものだと いうことを説明するには「ロボット学」がよいのかもしれ ません，一方，ロボット産業が確たる展望を見失っている かに見えるのにロボット学会の方では現実には遠い夢と先 走りすぎの研究が多いという批判があります。（梅谷先生 の言によれば A 工学と B 工学の議論）実体を確立すると いう意味では「ロボット工学」の方がよいのかも知れませ ん。なかなか悩ましい問題です。

次に「「ロボット工学」や「ロボット」に定義を与えよう とする議論ですが，私は学問体系は歴史的に変わっていく もので，後々の発展を阻害しないためにもあまり厳格に定 義しないほうがよいと思います。

現在の技術レベルのもとでロボット工学の核となるもの を考えてゆくためには，私はロボットとは「人間と調和し た自律的汎用人工物」であり，ロボット工学とはこのロボ ットを実現するための学問，技術であるとしてはどうかと 思います。ここでの汎用はロボットがあくまで人間の道具 であることを意味します。ロボットが人間の理解に役立つ ことは事実で，人工生命の研究も興味深いものではありま すが，実態的にみて当面はロボット工学の副産物としたほ うが妥当かと思われます。人工物を機械としなかったのは ハードウェアだけに限定せず，システムとそのソフトウェ アも含めたいと考えたからです.

このように考え，立命館大学の「ロボティクス学科」で はメカニズム，アクチュエータ，センサ，コントローラ等 とそれらをシステムとして構築することをあつかうロボッ トシステム分野，ロボットにスキルを実現し自律的に作業 させるため知能，環境を理解させるためのロボットビジョ ン，ロボット用人工知能をあつかうロボット知能分野，口 ボットと人間のインターフェイスを研究教育するヒューマ ンマシン分野の 3 分野を設定しました.

坪内：ロボット工学とはなんぞやといわれた時，ある意味 で，『知能機能集積工学』といったら笑われますでしょう
か？もうちょっと字間を埋めると，『(ある用途目的をも つ機械系を構成するために必要な）知能及び機能を集積 し，さらに洗練するための工学』です。集積するのですか ら，どんな分野からの話を持ってきても良い。その意味で は本当にゴッチャ煮です．しかし，その混沌の中から，あ る目的のために糸を引つ張りあげてついてきたものを，さ らにうまく洗練する，ということがキーになると思いま す。したがって，学ぶ者は，このような問題設定に対して は，このような手段（複数）を用い，それをこのように取 捨選択改良して，統合して，洗練したのだなあ，という流 れを摑むことが必要ではないでしょうか？

また別の議論ですが，これは聞いた話で，CMUのDr. Pradeep Khosla があるパネル討論会で, 『AI 研究者は, $\mathrm{AI}$ の一つのインプリメンテーションにロボットを考えて いる，で，ロボット研究者としての，そのインプリメンテ ーションの手段はメカトロニクスではないか』と述べたそ うです。いずれにしろ，『メカトロニクス』というキーワー ドは，我々にとっても大事にしてゆくべきキーワードかも しれません。

『ロボット工学』は，『ロボットを作る』学問と捉えなく ても，ロボット的な要素を持つ機械系を実現するための要 素技術の開発を伴う学問だと捉えても良いのではないか, と考えます。

市川：同感です。ロボットについて学んで社会にでてから もロボットを研究できる例は多くありません，しかし，坪 内先生の「ロボット的な要素を持つ機械系」というように 学生の方に幅広くとらえていただくと, 活躍の範囲が広が ります。

音田：私もメカトロニクスは大事だと思っています。コン ピュータを使っているというだけでなく，機械の設計とも 電気の設計とも違うような, メカトロニクスの独自の設計 論みたいなものはあるのでしょうか。 そしてそれは徐々に ひとつの体系となりつつあるのでしょうか. それともノウ 八ウの蓄積が行われているところなのでしょうか.

「ロボット工学」の授業などでは，現在の技術レベルを勘 案しながら「人類の歴史や文明の流れのなかで, 何が要求 されているのか，どのようなことが科学技術の側から提案 できるのか」，最初だけでもこの種の方向づけやきっかけ を提供しておくのは必須ではないでしょうか. あとはもち ろん自分で考えるわけですが，立命館のカリキュラムの 「ロボティクスの意義と今後の課題」というのは?

前田：高校生向けのパンフレットには「21 世紀はロボット が人間の友となる時代であり，人類は機械との新しい出会 いに遭遇していると言えます。ロボットが従来の機械と大 きく異なるところは, 人間と会話したり, 自分で判断して 行動するといった高度な知能をもつことはもとより，人間 の体や心に対して『優しさ』を求められる点です」と技術 
史的意義を説明しました。また，具体的な社会ニーズとし て,「地球的諸問題に対する貢献」,「高度産業社会」,「豊 かな長寿社会と快適な個人生活」のための様々なロボット を挙げています。このようなロボットを開発するのに必要 な技術課題を解決してゆくのが目標です。また， ロボティ クスはまだまだ若い学問であり, 心にバリアをつくらず上 記の目標実現に必要なものは何でも取り入れてゆくこと, 自分で問題意識をもって勉強することが最も大切であるこ とを徹底的に強調するつもりです，ロボット工学を「ロボ ット的要素をもつ機械系を実現するための学問」というの は, 全く同感です.

坪内：私は，ロボット関連の要素技術を開発してゆくため には，いろいろな幅の広い横断的な知識が必要になってく るので，もともと何にでも応用が効くような，オールマイ ティ的な人がロボット工学科では育つと思います，そのオ 一ルマイティさが器用貧乏でなく, バランスのとれた洗練 されたシステムを作りあげる方向に働かすことができる能 力である必要があるでしょうけれども.

横井：まさにその通りだと思います。ただし，広く学ぶこ とは浅く学ぶことに成りがちなので, そこが難しいところ でしょうね，実際にロボットを作ったり，動かしたりする ことによって, 学問 (理論) と実際の関係を理解させ, 講 義以外にも自習する意欲を育むことが大切な気がします。

前田：その点を考慮して, 我々の学科のカリキュラムには 「ロボット製作実習」や「ロボット作業実習」などを設けて います．ただ，私は現在の産業用ロボットの使い方だけを 教えるのは将来性がなく大学の教育に值しないと考えてい ます. 現在のロボット言語もそうです. 少し先走りかも知 れませんが,「ロボット作業実習」では, 力, インピーダン ス制御も必要な人間の熟練やスキルを要する作業をどう実 行するかを訓練したいと考えています。直接的に関係のあ る講義として「ロボット作業工学」と「接触工学」を用意 しています。この演習では軽作業用のロボットと運動/力/ インピーダンス制御ができる新設計のコントローラを 10 組用意して, 課題作業に対してどれだけうまい作業戦略を 考案し, 実行させるかを競わせてみたいと考え, システム
を準備中です．学科の $1 / 3$ はロボットをうまく使うプログ ラムがつくれる技術者の養成を目標としています。

音田：ロボット工学のカリキュラムとしては, ニーズを優 先させた選択もあれば, シーズを優先させた選択もある し，その他，きちんとした方針に基づいてさえいれば，選 び方のバリエーションは基本的なものがいくつか存在する と思います。

前田：カリキュラムに関してはそのとおりですね，ただ， 社会ニーズに対する研究や学会のありかたに関して最近私 が気になる点がありまして，それを話させていただきま す．社会ニーズは，社会資本を投じるプロジェクトにおい てはロボット研究者以外の人にロボットの必要性を認知さ せる上で不可欠です。このための論理としては A 工学が 必要となります，B工学だけでは不十分です，学問体系と はひとつのまとめかたであり, 科学技術においてもいろい ろなまとめかたが可能です．このために必要な核となる固 有の技術や A 工学の中味について議論するのがこの座談 会の重要な目的ではないかと思います。ただ，ロボットだ けがすべてではありません，いちどロボットからはなれて ものをみることが必要かも知れませんね.

白井：これまで, 学問分野の名前をつけた工学や学科とも のの名前をつけたものがあります。ものの価值は, 時代と ともに変わるので，それを名前にすることはよくないとい う議論があります，確かにそうですが，ロボットは違うと 私は自分の学科で主張しています。ロボットは特定のもの ではなく，人間のようにあるいは人間以上に器用で, 運動 能力があり，環境認識ができ，考えることができるもので あり，その定義は時代とともに変わるので，「ロボットを 対象とする学問は永遠である」と言っています。

備考：『群ロボット』に関する多くの興味深い議論や, 前田先生 によるロボティクス学科の丁寧な解説がありましたが, 割愛させていただいた。

企画・編集：市川 誠（清水建設(株)) 媣瀬勇太郎（清水建設(株)） 